Е. М. Сергеева

Белорусский государственный технологический университет

\title{
ОСОБЕННОСТИ ПРАВОВОГО РЕГУЛИРОВАНИЯ ПРОТИВОДЕЙСТВИЯ РАСПРОСТРАНЕНИЮ СОУІD-19 В РЕСПУБЛИКЕ БЕЛАРУСЬ
}

\begin{abstract}
В настоящее время весь мир находится в состоянии противодействия глобальной эпидемии COVID-19, что требует от каждого государства принятия мер к максимальной защите населения от заражения. Для предупреждения глобального распространения мировой эпидемии необходимо принятие целого ряда мер ограничительного характера, направленных на уменьшение опасных последствий мировой пандемии.

В статье рассматривается правовая регламентация пересечения границы Республики Беларусь в условиях пандемии и предпринятые меры по максимальному предотвращению завоза на территорию страны опасного вируса.
\end{abstract}

Ключевые слова: эпидемия, ограничение, меры, государство, контроль.

Для цитирования: Сергеева Е. М. Особенности правового регулирования противодействия распространению COVID-19 в Республике Беларусь // Труды БГТУ. Сер. 6, История, философия. 2021. № 2 (251). C. 107-110.

\section{Ye. M. Sergeeva \\ Belarusian State Technological University \\ FEATURES OF LEGAL REGULATION COVID-19 COUNTERPROOF IN THE REPUBLIC OF BELARUS}

Currently, the whole world is in a state of opposition to the global COVID-19, which requires each state to take measures to maximize the protection of the population from infection. To prevent the global spread of the world epidemic, it is necessary to take a number of restrictive measures aimed at reducing the dangerous consequences of the global pandemic.

The article discusses the legal regulation of crossing the border of the Republic of Belarus in a pandemic and the measures taken to prevent the introduction of a dangerous virus into the country as much as possible.

Key words: epidemic, restriction, measures, state, control.

For citation: Features of legal regulation COVID-19 counterproof in the Republic of Belarus. Proceedings of BSTU, issue 6, History, Philosophy, 2021, no. 2 (251), pp. 107-110 (In Russian).

Введение. Особую значимость и интерес представляет законодательная регламентация обеспечения здравоохранительной функции государства и государственных органов в контексте противодействия распространению COVID-19.

Основная часть. Предупреждение глобального распространения мировой эпидемии, минимально возможные ограничения для уменьшения опасных последствий обладают рядом особенностей. Содержание и реализация конституционных гарантий права на свободу передвигаться в Республике Беларусь и за ее пределами, а также права на охрану здоровья зависит от ценностной ориентации, представляющей собой сознательную, устойчиво активную направленность государства, государственных органов, органов управления и самоуправления, организаций и каждой личности, основанную на представлениях о справедливости, равенстве, свободе и других общепризнанных социальных ориентирах [1].
Сложность для правового обеспечения, незамедлительной реализации и исследования представляет прежде всего значительная самостоятельность в этой сфере, предоставляемая правовыми актами органам государственного управления, местным органам власти и самоуправления, а также одновременное влияние социального и психологического факторов.

Осуществляя меры по эпидемиологическому противодействию такому общеопасному явлению, как распространение в мире короновируса, нельзя выделить какие-то отдельные, особенно эффективные меры. Достижение позитивного результата, на который направлены усилия, возможно лишь при использовании комплекса принудительных, социальных, просветительских и других мер. Центральное место в их ряду принадлежит, конечно, мероприятиям правового характера достаточно широкого спектра, к числу которых относится в первую очередь законодательная политика государства. 
В целях снижения риска распространения в Республике Беларусь инфекции, вызванной короновирусом COVID-19 (далее - инфекция COVID-19), упорядочения международных автомобильных перевозок и на основании статьи 7 Закона Республики Беларусь от 7 января 2012 г. № 340-3 «O санитарно-эпидемиологическом благополучии населения» Совет Министров Республики Беларусь постановил, что лица, прибывшие в Республику Беларусь из стран, в которых регистрируются случаи инфекции COVID19 (далее - прибывшие лица), в течение 14 календарных дней со дня прибытия в Республику Беларусь должны находиться в самоизоляции и не подлежат последующему пропуску через Государственную границу Республики Беларусь (до истечения срока самоизоляции).

Установлены определенные новшества в деятельности государственных органов в этой сфере. В вышеназванном постановлении порядок взаимодействия органов государственного управления и иных организаций по обеспечению соблюдения мер самоизоляции прибывшими лицами определяется Министерством здравоохранения, Министерством внутренних дел и Государственным пограничным комитетом. Также определено направление действий Министерству транспорта и коммуникаций, Государственному таможенному комитету.

Министерство иностранных дел информировало по дипломатическим каналам иностранные государства о принятии постановления.

Меры, принимаемые различными странами, которые направлены на защиту своего населения от заболевания, обладают рядом правовых особенностей, значительно ограничивающих передвижения всех видов.

Особый интерес представляет законодательная регламентация обеспечения здравоохранительной функции государства и государственных органов в контексте противодействия распространению COVID-19 при осуществлении туристической деятельности в Республики Беларусь.

Объективную сложность для законодательного обеспечения и изучения представляет, прежде всего, деятельность такой сферы, как международный туризм в целом, и деятельность непосредственно туристических организаций по причине недостаточно четкой правовой регламентации, значительной самостоятельности в этой сфере, предоставляемой локальными актами органам управления, а также одновременного влияния социального и психологического факторов.

Осуществляя меры по эпидемиологическому противодействию такому общеопасному явлению, как распространение в мире короновируса по причине пересечения границ активно путешествующими лицами, нельзя выделить какие-то отдельные, особенно эффективные меры. Достижение результата, на который направлены такие усилия, возможно лишь при использовании комплекса социальных, просветительских и других мер. Центральное место в их ряду принадлежит, конечно, мероприятиям правового характера достаточно широкого спектра, к числу которых относится в первую очередь законодательная политика государства.

Наиболее значимым и достаточно своевременным явилось принятие Постановление Совета Министров Республики Беларусь от 25 марта 2020 г. № 171 «О мерах по предотвращению завоза и распространения инфекции, вызванной коронавирусом COVID-19».

Совет Министров установил, что вышесказанное не распространяется на следующих лиц:

- сотрудников дипломатических представительств, консульских учреждений иностранных государств в Республике Беларусь и аккредитованных по совместительству с резиденциями в других странах, международных организаций и их представительств, расположенных на территории Республики Беларусь, а также членов их семей;

- глав и членов официальных делегаций;

- водителей транспортных средств при выполнении международных автомобильных перевозок грузов;

- членов экипажей воздушных судов, судов внутреннего водного транспорта, поездных бригад, локомотивных бригад международного железнодорожного сообщения;

- иностранцев, следующих транзитом через территорию Республики Беларусь для возвращения к месту жительства.

Перечень стран, в которых регистрируются случаи инфекции COVID-19, размещается на официальном сайте Министерства здравоохранения в глобальной компьютерной сети Интернет.

Сотрудники органов пограничной службы выдают прибывшим лицам анкету прибывшего по форме, установленной Министерством здравоохранения. После заполнения анкета передается сотрудниками органов пограничной службы должностным лицам Министерства здравоохранения.

Правила поведения прибывших лиц, находящихся в самоизоляции, определяются Министерством здравоохранения.

Порядок взаимодействия органов государственного управления и иных организаций по обеспечению соблюдения мер самоизоляции прибывшими лицами определяется Министерством здравоохранения, Министерством внутренних дел и Государственным пограничным комитетом. 
Водители, выполняющие транзитные автомобильные перевозки грузов через территорию Республики Беларусь, в том числе с территории Российской Федерации в государства - члены Европейского союза и Украину, между двумя пунктами пересечения Государственной границы Республики Беларусь в местах, установленных законодательством (далее - транзитные перевозки), обязаны проезжать только по республиканским автомобильным дорогам, на которых возможна остановка (стоянка) для отдыха и питания водителей, заправки транспортных средств, согласно перечню дорог и специализированных мест.

Водители, выполняющие транзитные перевозки, обязаны покинуть территорию Республики Беларусь по кратчайшему маршруту не позднее дня, следующего за днем въезда на ее территорию, за исключением случаев, когда невозможность соблюдения указанного срока обусловлена аварией (поломкой) транспортного средства, а также разгрузкой, перегрузкой (перевалкой) груза, заменой транспортного средства, если это предусмотрено условиями договора автомобильной перевозки и указано в транспортных документах.

В случае необходимости допускается отклонение от республиканской автомобильной дороги, указанной в перечне дорог и специализированных мест. Необходимые операции должны быть осуществлены в минимальные сроки. В период остановки (стоянки) водители, выполняющие транзитные перевозки, не должны покидать территорию пунктов остановки (стоянки) для отдыха и питания водителей, заправки транспортных средств согласно перечню дорог и специализированных мест.

Министерству транспорта и коммуникаций следует:

- обеспечить тиражирование карты республиканских автомобильных дорог и пунктов остановки (стоянки) для отдыха и питания водителей, заправки транспортных средств, содержащей сведения, указанные в перечне дорог и специализированных мест, на русском и английском языках для передачи государственным органам, осуществляющим таможенный контроль в пунктах пропуска через Государственную границу Республики Беларусь;

- обеспечить размещение перечня дорог и специализированных мест на его официальном сайте в глобальной компьютерной сети Интернет;

- организовать установку информационных щитов с указанной картой на въездах в Республику Беларусь.

Государственному таможенному комитету в пунктах пропуска на белорусском участке внешней границы Евразийского экономического союза, Транспортной инспекции Министерства транспорта и коммуникаций в рамках проведения контрольных мероприятий на приграничной территории белорусско-российского участка Государственной границы Республики Беларусь следует организовать вручение водителям, выполняющим международные автомобильные перевозки грузов, требований по утвержденной форме и ознакомление с ними.

Данные требования оформляются в двух экземплярах, один из которых вручается водителю либо прикрепляется к транспортному документу, второй остается в делах таможенного органа или Транспортной инспекции Министерства транспорта и коммуникаций.

Государственному таможенному комитету поручено обеспечить установление срока таможенного транзита до конечного пункта назначения с учетом требований названного постановления.

Министерству здравоохранения совместно с облисполкомами следует организовать контроль за проведением санитарно-противоэпидемических мероприятий в пунктах остановки (стоянки) для отдыха и питания водителей, заправки транспортных средств согласно перечню дорог и специализированных мест.

Облисполкомам совместно с Белорусским государственным концерном по нефти и химии указано принять необходимые меры по обеспечению персонала, осуществляющего свои функции в пунктах остановки (стоянки) для отдыха и питания водителей, заправки транспортных средств, указанных в перечне дорог и специализированных мест, средствами индивидуальной защиты (медицинские маски, перчатки) и контролю выполнения рекомендаций Министерства здравоохранения.

За неисполнение требований прибывшие лица, а также водители, выполняющие транзитные перевозки, несут ответственность, предусмотренную законодательством.

Контроль за выполнением постановления возложен на Министерство здравоохранения, Министерство внутренних дел, Министерство транспорта и коммуникаций, Министерство иностранных дел, Государственный пограничный комитет, Государственный таможенный комитет, Белорусский государственный концерн по нефти и химии, облисполкомы в соответствии с компетенцией [2].

Заключение. Поскольку в настоящее время очевидно, что глобального распространения мировой эпидемии не удалось предотвратить, каждое государство обязано вводить минимально возможные ограничения для уменьшения опасных последствий, которые несомненно обладают рядом правовых особенностей, значительно ограничивающих все виды пересечений государственной границы Республики Беларусь. 


\section{Список литературы}

1. Конституция Республики Беларусь 1994 года (с изменениями и дополнениями, принятыми на республиканских референдумах 24 ноября 1996 г. и 17 октября 2004 г.). Минск: Амалфея, 2005. 48 с.

2. О мерах по предотвращению завоза и распространения инфекции, вызванной коронавирусом COVID-19: постановление Совета Министров Республики Беларусь от 25 марта 2020 г. № 171 // Национальный реестр правовых актов Республики Беларусь, 29.05.2020. 5/48097.

\section{References}

1. Konstitutsiya Respubliki Belarus 1994 goda (s izmeneniyami $i$ dopolneniyami, prinyatymi na respublikanskikh referendumakh 24 noyabrya 1996 g. $i 17$ oktyabrya 2004 g.) [Constitution of the Republic of Belarus of 1994 (amended, adopted at the national referendum November 24, 1996 and October 17, 2004)]. Minsk, Amalfeya Publ., 2011. 48 p.

2. On measures to prevent the importation and spread of infection caused by the coronavirus COVID-19: Resolution of the Council of Ministers of the Republic of Belarus dated March 25, 2020 no. 171. Natsional'nyy reestr pravovykh aktov Respubliki Belarus' [National register of legal acts of Republic of Belarus], 29.05.2020, 5/48097.

\section{Информация об авторе}

Сергеева Евгения Михайловна - ассистент кафедры философии и права. Белорусский государственный технологический университет (220006, г. Минск, ул. Свердлова, 13a, Республика Беларусь). E-mail: sergeeva@belstu.by

\section{Information about the author}

Sergeeva Yevgeniya Mikhaylovna - assistant lecturer, the Department of Philosophy and Law. Belarusian State Technological University (13a, Sverdlova str., 220006, Minsk, Republic of Belarus). E-mail: sergeeva@belstu.by 